\title{
PENAMBAHAN TEPUNG PORANG PADA PEMBUATAN MI DENGAN SUBSTITUSI TEPUNG MOCAF (Modified cassava FLOUR)
}

\author{
[Addition of Porang Flour in Noodle as Mocaf Substitution (Modified cassava Flour)]
}

\author{
Anni Faridah ${ }^{1)^{*}}$ dan Simon Bambang Widjanarko2) \\ 1) Fakultas Teknik, Univeritas Negeri Padang, Padang \\ 2) Fakultas Teknologi Pertanian, Universitas Brawijaya, Malang
}

Diterima 16 Januari 2014 / Disetujui 25 Juni 2014

\begin{abstract}
Noodle is one of the staple foods that are widely consumed and preferred by the Asian. However, wet noodles with modified cassava flour (mocaf) substitution resulted in lower quality compared to $100 \%$ wheat noodle. Addition of a certain amount of konjac glucomannan (Amorphophallus oncophyllus flour) to wet noodle is strongly recommended due to the fact that the food additive has a health benefit. Porang or konjac flour, which was used in the research, has soluble fiber properties, low calorie content, and highly viscous. It forms a heat stable gel with a mild alkali, interacts with starch, and has a synergistic interaction with kappa carrageenan. In this research, konjac flour was added to study the optimum combination between konjac and water. As much as 2, 4 and 6\% (w/w) of konjac flour were combined with 35, 40, 45\% (v/w) of water. The results showed that treatments with combinations of konjac flour and water were significantly contributing to characteristics of cooking time, cooking loss, color brightness index, tensile strength, swelling volume and water absorption. The best treatment was at a combination of $4 \%$ konjac (w/w) and $35 \%$ water $(\mathrm{V} / \mathrm{W})$. The best porang noodles have the characteristics of cooking time at 2.13 minutes, cooking loss of $35 \%$, tensile strength of $0.14 \mathrm{~N}$, water absorption of $201.58 \%$, color brightness index of 51.41 , swelling volume of $103.63 \%$, moisture content of $31.77 \%$, protein content of $5.87 \%$, fat content of $2.13 \%$, ash content of $0.85 \%$ and crude dietary fiber of $4.58 \%$.
\end{abstract}

Kaywords: glucomannan, mocaf, porang flour, wet noodle

\section{ABSTRAK}

Mi basah merupakan salah satu jenis makanan pokok yang banyak dikonsumsi dan disukai masyarakat Asia. Namun mi basah hasil subtitusi dengan tepung mocaf memiliki kualitas yang lebih rendah dibanding menggunakan $100 \%$ terigu, sehingga perlu ditambahkan bahan tambahan pangan yang juga bersifat baik untuk kesehatan. Tepung porang adalah jenis serat yang larut dalam air. Tepung ini memiliki kandungan kalori yang rendah dan visikositas tinggi. Tepung porang dapat membentuk gel yang stabil pada kondisi panas dengan penambahan alkali ringan, berinteraksi dengan pati dan bersifat sinergi dengan kappa karagenan. Dalam penelitian ini ditambahkan tepung porang, maka perlu dicari jumlah tepung porang dan air (faktorial) yang tepat untuk menghasilkan mi basah sesuai standard. Konsentrasi tepung porang yang ditambahkan 2, 4 dan 6\% (w/w), dan persentasi air 35, 40 dan 45\% (v/w). Hasil Penelitian menunjukkan bahwa perlakuan dengan penambahan tepung porang dan air berpengaruh nyata terhadap karakteristik parameter cooking time, cooking loss, kecerahan warna, daya putus, volume pengembangan, water absorption. Perlakuan terbaik mi porang diperoleh pada kombinasi perlakuan penambahan tepung porang $4 \%$ dan air $35 \%$. Produk mi porang tersebut memiliki karakteristik cooking time 2.13 menit, cooking loss $7.03 \%$, daya putus (tensile strength) $0.14 \mathrm{~N}$, water absorption $201.58 \%$, kecerahan warna 51.41 , volume pengembangan $103.63 \%$, kadar air $31.77 \%$, kadar protein $5.87 \%$, kadar lemak $2.13 \%$, kadar abu $0.85 \%$, kadar serat kasar $4.58 \%$.

Kata kunci: glukomanan, mocaf, mi basah, tepung porang

\section{PENDAHULUAN}

Mi merupakan salah satu makanan utama di Asia. 20-50\% gandum Asia (Fu, 2008; Hou, 2010), dan 12\% gandum dunia (Ganet al. 2009) digunakan untuk produksi mi. Mi telah menjadi salah satu pangan alternatif pengganti nasi di Indonesia. Hal ini sangat menguntungkan, jika ditinjau dari sudut pandang penganekaragaman konsumsi pangan, karena konsumsi pangan tidak hanya bergantung kepada beras. Pembuatan mi yang disubstitusi dengan bahan pangan lokal dapat mengurangi

*Penulis Korespondensi:

E-mail: anni_lubis@yahoo.com penggunaan terigu. Namun demikian, tepung bahan lain belum mampu sepenuhnya berperan menggantikan terigu karena tidak mengandung gluten, sehingga tepung dari bahan pangan lokal rata-rata baru bisa mensubstitusi terigu sekitar $25-30 \%$, terutama untuk aneka roti dan mi (Ratnaningsih et al. 2010).

Mi adalah produk makanan yang dibuat dari tepung terigu dengan atau tanpa penambahan bahan makanan lain dan bahan tambahan makanan yang diizinkan, berbentuk khas mi yang tidak dikeringkan (BSN, 1992). Mi memiliki masa simpan pendek karena memiliki kandungan airnyatinggi ( $\mathrm{Xu}$ et al. 2008), meskipun begitu mayoritas masyarakat China dan Asia lebih menyukai mi atau mi segar karena rasa dan aromanya yang masih khas (Hou, 2010). 
Elastisitas dan kekenyalan tekstur mi dapat ditingkatkan dengan menggunakan bahan tambahan pangan (Carini et al. 2009). Beberapa bahan tambahan pangan (BTM) yang telah digunakan dalam pembuatan mi antara lain gum (Charles et al. 2007), enzim (Wu dan Corke, 2005), isolat protein kedelai, kasein, kitosan, dan pati pregelatinisasi (Chillo et al. 2009), xanthan gum, guar gum, locust bean gum, konjak glukomanan dan hydroxypropyl methylcellulose. Pada pembuatan mi ditambahkan 0.5-1\% BTM (Silva et al. 2013). Namun demikian belum ditemukan pustaka penggunaan tepung porang atau porang glukomanan dalam pembuatan mi subtitusi berbahan dasar terigu dan Modified Casava Flour (MOCAF). Tepung porang adalah jenis serat yang larut dalam air. Tepung ini memiliki kandungan kalori yang rendah dan visikositas tinggi. Tepung porang dapat membentuk gel dan stabil pada kondisi panas dengan penambahan alkali ringan, berinteraksi dengan pati dan bersifat sinergi dengan kappa karagenan (Wang dan Johnson, 2006).

Menurut Collado dan Corke (2004), secara umum formulasi pembuatan mi adalah sederhana dan mudah, yaitu terdiri atas air (30-38\%), tepung, dan garam atau kansui dengan proses pencampuran, pemipihan, pencetakan, perebusan, dan pelumasan dengan minyak. Tujuan penelitian ini adalah menganalisis komposisi tepung porang atau porang glukomanan dan air dalam pembuatan mi yang disubstitusi dengan MOCAF.

\section{BAHAN DAN METODE}

\section{Bahan}

Tepung porang optimasi pencucian maserasi hasil penelitian sebelumnya dengan kadar glukomanan $80.17 \%$, MOCAF produksi Koperasi Gemah Ripah Loh Jinawi Trenggalek. Bahan lain adalah tepung terigu merk "Cakra Kembar", garam dapur, minyak goreng merk "Sunco", dan telur yang diperoleh dari pasar tradisional lokal.

\section{Rancangan penelitian}

Pembuatan mi menggunakan metode Rancangan Acak Lengkap (RAL) yang disusun secara faktorial (2 faktor), yaitu faktor I konsentrasi tepung porang dan faktor II proporsi air, dengan 3 kali ulangan. Faktor I Konsentrasi Tepung Porang $(P)$ (2, 4 dan 6\%), faktor II Persentase Air (A) (35, 40 dan 45\%), sehingga dihasilkan kombinasi perlakuan sebagai berikut: P1A1, P1A2, P1A3, P2A1, P2A2, P2A3, P3A1, P3A2, P3A3. Konjak glukomanan telah digunakan dalam pembuatan mi pada tingkat konsentrasi $0.5-1 \%$ (Silva et al. 2013). Pemilihan proporsi 2,4 dan $6 \%$ bertujuan untuk mengetahui pengaruhnya terhadap sifat fisikokimia mi dan ingin meningkatkan kadar glukomanan mi karena glukomanan merupakan pangan fungsional.

\section{Pembuatan gel porang}

Tepung porang dengan ragam konsentrasi 2, 4, 6\% (b/b) dan air (pada suhu kamar) dengan ragam konsentrasi 30, 35, $40 \%$ (b/b) (persentase per 100 gram tepung) dicampurkan, kemudian dibiarkanselama 10 menit pada suhu kamar untuk memberikan waktu pada tepung porang agar dapat menyerap air dan swelling dengan baik. Tahap ini dilakukan karena dalam penelitian pendahuluan (cara membuat mi) diketahui hasil mi porang terbaik adalah dengan membuat gel porang terlebih dahulu. Cara membuat mi dengan langsung mencampurkan semua bahan menjadi satu akan menghasilkan sifat fisiknya yang kurang maksimal.

\section{Pembuatan mi}

Tepung terigu dicampur dengan MOCAF, konsentrasi 75:25 lalu ditambahkan bahan pembantu lain seperti garam dapur sebanyak $2 \%$, telur $10 \%$, minyak $10 \%$. Dan pengadukan dilakukan dengan mixer selama 5 menit agar adonan tercampur secara merata, lalu gel porang dimasukkan. Kemudian pengadukan dilakukan menggunakan mixer (philips HR 1538/80, Japan) selama 5 menit hingga adonan homogen. Setelah adonan yang terbentuk sudah homogen (gel porang sudah tercampur merata) maka adonan didiamkan selama 5 menit yang berfungsi untuk membantu air bereaksi membentuk gluten. Kemudian pemipihan adonan dilakukan menggunakan roll pressing (sheeter) (CLE-168, Germany) hingga terbentuk lembaran adonan setebal $2 \pm 0.5 \mathrm{~mm}$. Lembaran mi dicetak menggunakan noodle maker untuk dibentuk menjadi untaian mi porang. Untaian mi tersebut direbus pada air mendidih selama 1-3 menit, kemudian ditiriskan dan siap untuk dianalisa.

\section{Analisis waktu pemasakan (Huang dan Hsi, 2010)}

5 gram sampel mi dimasak dalam air mendidih $75 \mathrm{~mL}$ sehingga tergelatinisasi sempurna. Setiap sekitar 3 menit sekali diambil 1 untaian mi untuk dilihat apakah dalamnya sudah matang. Lama pemasakan diamati sebagai waktu gelatinisasi dari mi tersebut.

\section{Analisiskehilangan padatan akibat pemasakan (KPAP) (Huang dan Hsi, 2010)}

Kehilangan padatan akibat pemasakan dapat dilakukan dengan merebus 2 gram sampel mi dalam $100 \mathrm{~mL}$ air mendidih sampai mi tergelatinisasi sempurna. Mi diangkat dan air bekas seduhan dikeringkan dalam oven hingga beratnya konstan. Kehilangan padatan ini menggambarkan lolosnya bahan padatan ke dalam air perebus sehingga mengurangi total padatan mi.

\section{Perhitungan: (berat akhir/berat awal) x 100\%}

\section{Analisis daya serap air (AACC 2000 dalam Lase et al. 2013)}

5 gram sampel mi mentah dimasukkan kedalam air mendidih $100 \mathrm{~mL}$, lalu ditutup, dan dimasak sampai mi tergelatinisasi sempurna. Mi yang telah masak sempurna ditimbang. Penyerapan air diukur berdasarkan perubahan sebelum dan sesudah pemasakan

\section{Daya serap air $=$ Berat sampel masak $\times 100 \%$ Berat sampel mentah}

\section{Analisis daya putus}

Analisa daya putus dilakukan dengan cara menjepit sampel mi pada pengait tensile strength (UT 2040, Japan). Mesin 
tensile strength dijalankan melalui komputer sehingga mi tertarik sampai putus, lalu nilai daya putus dibaca pada monitor.

\section{Analisis statistik}

Metode analisis sidik ragam (ANOVA = Analysis of Variance) dilanjutkan dengan uji Least Significant Difference (Fischer's LSD) atau Duncan's Multiple Range Test (DMRT) digunakan untuk menguji hasil analisis cooking quality dan analisisfisik lainnya. Analisis data menggunakan selang kepercayaan sebesar 5 dan 1\%. Pemilihan perlakuan terbaik dilakukan dengan metode indeks efektifitas (De-Garmo et al. (1984). Pada perlakuan terbaik dianalisis karakteristik fisik dan karakteristik kimia mi. Karakteristik fisik yang dianalisis yaitu waktu pemasakan, KPAP, daya putus, daya serap air, warna, volume pengembangan.Karakteritik kimia mi dianalisis seperti analisis proksimat (kadar air, kadar protein, kadar karbohidrat, dan lemak, kadar abu dan serat kasar) (AOAC, 2000). Analisis Volume Pengembangan (AACC, 2000 dalam Lase et al. 2013), Analisis Kecerahan Warna (AACC, 2000 dalam Lase et al. 2013). Analisis mikrostruktur mi basah dilakukan menggunakan Scanning Electron Microscopic (SEM) (JSM T-100, JEOL, Jepan).

\section{HASIL DAN PEMBAHASAN}

\section{Waktu pemasakan}

Rerata nilai waktu pemasakan mi basah pada berbagai kombinasi konsentrasi tepung porang dan air berkisar antara 1.14-3.52 menit. Pengaruh perbedaan konsentrasi penambahan tepung porang dan air terhadap waktu pemasakan dapat dilihat pada Tabel 1.

Tabel 1. Pengaruh penambahan tepung porang dan air terhadap waktu pemasakan, KPAP, daya serap air, dan daya putusmi

\begin{tabular}{|c|c|c|c|c|c|}
\hline $\begin{array}{c}\text { Tepung } \\
\text { Porang } \\
(\%)\end{array}$ & $\begin{array}{l}\text { Air } \\
(\%)\end{array}$ & $\begin{array}{l}\text { Waktu Pe- } \\
\text { masakan } \\
\text { (menit) }\end{array}$ & $\begin{array}{c}\text { KPAP } \\
(\%)\end{array}$ & $\begin{array}{c}\text { Daya } \\
\text { Serap Air } \\
(\%)\end{array}$ & $\begin{array}{l}\text { Daya Putus } \\
\text { (N) }\end{array}$ \\
\hline \multirow{6}{*}{2} & \multirow[t]{2}{*}{30} & $3.52^{\mathrm{e}} \pm$ & $7.17^{\mathrm{a}} \pm$ & $166.79^{a} \pm$ & $0.1067^{b} \pm$ \\
\hline & & 0.16 & 1.80 & 3.61 & 0.01 \\
\hline & \multirow[t]{2}{*}{35} & $3.10^{d} \pm$ & $8.61^{b \pm}$ & $180.80^{\mathrm{b}} \pm$ & $0.1433^{c} \pm$ \\
\hline & & 0.12 & 2.37 & 1.82 & 0.01 \\
\hline & \multirow[t]{2}{*}{40} & $3.09^{d} \pm$ & $8.98^{b} \pm$ & $193.09^{b c} \pm$ & $0.1400^{\circ} \pm$ \\
\hline & & 0.07 & 0.99 & 2.67 & 0.01 \\
\hline \multirow{6}{*}{4} & \multirow[t]{2}{*}{30} & $2.88^{d} \pm$ & $11.26^{b c} \pm$ & $175.35^{\mathrm{ab}} \pm$ & $0.0967^{b} \pm$ \\
\hline & & 0.07 & 1.27 & 8.22 & 0.01 \\
\hline & \multirow[t]{2}{*}{35} & $2.13^{c} \pm$ & $7.03^{a b} \pm$ & $201.58^{c} \pm$ & $0.1367 c \pm$ \\
\hline & & 0.24 & 1.88 & 7.59 & 0.02 \\
\hline & \multirow[t]{2}{*}{40} & $1.61^{b} \pm$ & $4.67^{\mathrm{a}} \pm$ & $201.97^{c} \pm$ & $0.0967^{b} \pm$ \\
\hline & & 0.24 & 0.41 & 1.63 & $0 . \overline{01}$ \\
\hline \multirow{6}{*}{6} & \multirow[t]{2}{*}{30} & $1.43^{\mathrm{ab}} \pm$ & $16.30^{\circ} \pm$ & $181.99^{\mathrm{b}} \pm$ & $0.0533^{a} \pm$ \\
\hline & & 0.16 & 2.27 & 4.64 & 0.03 \\
\hline & \multirow[t]{2}{*}{35} & $1.31^{\mathrm{ab}} \pm$ & $14.30^{c} \pm$ & $213.52^{\mathrm{c}} \pm$ & $0.0567^{a} \pm$ \\
\hline & & $0.03^{-}$ & 1.19 & 5.68 & $0 . \overline{01}$ \\
\hline & \multirow[t]{2}{*}{40} & $1.14^{\mathrm{a}} \pm$ & $14.33^{\circ} \pm$ & $232.27^{d} \pm$ & $0.0733^{a} \pm$ \\
\hline & & 0.04 & 1.76 & 5.84 & 0.01 \\
\hline
\end{tabular}

Data pada Tabel 1. menjelaskan bahwa semakin banyak konsentrasi tepung porang dan air yang ditambahkan pada pembuatan mi basah mengakibatkan semakin menurunnya waktu pemasakannya. Khanna dan Tester (2006) menyatakan bahwa suhu dan lama gelatinisasi tergantung dari kandungan air dan banyaknya Purified Konjac Glucomannan (PKG). Penambahan stabilizer pada mi akan mempercepat waktu pemasakan, karena tepung porang memiliki kemampuan gelatinisasi lebih tinggi daripada tepung lainnya. Food Chemical Codex telah membuat daftar penggunaan tepung porang di AS sebagai agen pembuatan gel, pengental, pembentuk film, pembuat emulsi dan stabilisator, sehingga sehingga dengan penambahan tepung porang pada mi akan mempercepat waktu pemasakan mi tersebut.

Penelitian mi basah ini mengindikasikan semakin banyak penambahan air yang diberikan, maka waktu pemasakannya lebih singkat. Hal ini dikarenakan air dalam bahan akan memicu dan mempercepat proses gelatinisasi mi. Pada umumnya jumlah kandungan air yang semakin banyak akan mempercepat waktu gelatinisasi atau menurunkan suhu gelatinisasi (Alam et al. 2009). Choy et al. (2013) menyatakan semakin tinggi nilai daya serap air menyebabkan mi yang dihasilkan akan mudah lunak saat direbus. Menurut Fu (2008) untuk menjadikan mi segar menjadi mi diperlukan waktu pemasakan yang optimal sekitar 1-3 menit. Rentang waktu pemasakan pada penelitian ini sudah sesuai dengan literatur, yaitu dengan rerata waktu pemasakan sebesar 1.14-3.52 menit. Aravind (2012) melaporkan bahwa penambahan guar gum tidak mempengaruhi waktu pemasakan pada pembuatan spageti, namun semakin cepat pada penambahan $10 \%$.

\section{Kehilangan padatan akibat pemasakan (KPAP)}

KPAP adalah banyaknya padatan yang terkandung dalam mi yang keluar serta terlarut ke dalam air selama pemasakan. Mi yang baik diharapkan mempunyai nilai KPAP yang rendah. Rerata nilai KPAP mi basah pada kombinasi perlakuan penambahan tepung porang dan air adalah 4.67-16.30\%.

Tabel 1. menunjukkan bahwa nilai KPAP menurun dengan peningkatan tepung porang dan air dari 2 sampai $4 \%$. Zhang et al. (2005); Xiong (2007) menyampaikan bahwa tepung porang berfungsi sebagai bahan pengembang, pengental dan mampu mengikat air, sehingga molekul-molekul air terperangkap dalam struktur gel yang dibentuk dengan penambahan tepung porang, dengan demikian bahan-bahan padatan juga akan saling berikatan. Oleh karena itu, pada saat pemasakan kehilangan padatan akan semakin kecil.

KPAP meningkat dengan penambahan $6 \%$ tepung porang, hal ini diduga ketidakseimbangan jumlah air dengan tepung porang yang ditambahkan, sehingga terganggunya matrik protein-pati adonan mi. Jumlah tepung porang meningkat, sedangkan jumlah air tetap, maka air yang tersedia tidak mencukupi untuk membentuk adonan mi yang baik. Pembentukan adonan mi yang baik, yaitu terjadinya matrik proteinpati dengan adanya air yang cukup. Izydorczyk et al. (2005) melaporkan bahwa peningkatan KPAP disebabkan oleh melemahnya dan/atau gangguan dari matrik pati-protein. Pendapat yang sama juga dinyatakan Aravind (2012), bahwa KPAP semakin tinggi dengan semakin tingginya penambahan guar gum pada pembuatan spageti yang disebabkan oleh gangguan pada matrik pati-protein. Aydin dan Gocmen (2011) juga melaporkan bahwa penambahan tepung oat berpengaruh nyata terhadap KPAP mi dibandingkan dengan mi gandum, semakin banyak tepung yang ditambahkan, maka semakin 
tinggi nilai KPAP dari mi tersebut. Paragraf ini telah banyak perubahan sesuai dengan saran (sehingga lebih sistemasi dan informatif).

\section{Daya serap air}

Daya serap air yaitu kemampuan mi untuk menyerap air secara maksimal. Rerata daya serap air mi basah berkisar antara 166.79-232.27\%. Tabel 1 menunjukkan bahwa perlakuan dengan penambahan tepung porang 6\% dan air $40 \%$ memiliki rerata nilai daya serap air tertinggi, yaitu sebesar $232.27 \%$. Semakin tinggi penambahan tepung porang dan air, semakin tinggi daya serap air karena sifat dari tepung porang yang mudah menyerap air. Charoenrein et al. (2011) melaporkan bahwa tepung yang kaya glukomanan mempunyai sifat kelarutan yang tinggi, baik dalam air panas maupun dingin. Wang dan Johnson (2006) menyatakan bahwa tepung konjak mengandung kadar glukomanan yang tinggi, merupakan serat larut air, rendah kalori, daya serap air tinggi dan bebas gelatin, yang memiliki tingkat kekentalan paling tinggi secara alamiah. Sedangkan menurut Muhamed et al. (2005) jenis polisakarida yang larut air dapat meningkatkan daya serap air pada produk, sehingga dengan menambahkan tepung porang yang kaya glukomanan dalam pembuatan mi akan meningkatkan daya serap air mi tersebut. Aravind (2012) juga melaporkan bahwa semakin tinggi penambahan CMC dan guar gum, maka semakin tinggi daya serap air pada pembuatan spageti.

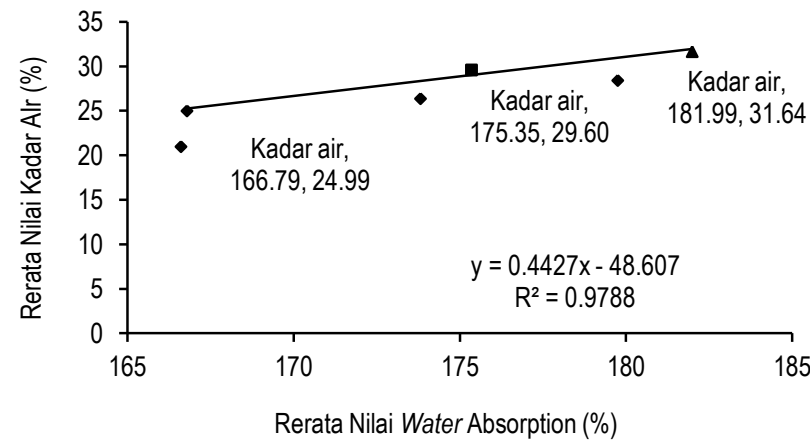

Gambar 1. Korelasi daya serap air dan kadar air

Gambar 1. menunjukkan daya serap air memiliki korelasi terhadap kadar air mi basah yang dihasilkan dengan nilai y = $0.442 x-48.60$ dan nilai $R^{2}$ sebesar 0.978 . Artinya semakin tinggi kemampuan mi menyerap air, maka kadar air mi basah juga akan semakin tinggi. Hal ini didukung dengan pernyataan Hou (2010) bahwa penambahan hidrokoloid pada proses pembuatan mi akan meningkatkan daya serap air, sehingga produk mi akan lebih mudah menyerap air.

\section{Daya putus}

Rerata daya putus mi basah pada kombinasi perlakuan penambahan tepung porang dan air adalah 0.0533-0.1400 Newton. Pengaruh penambahan tepung porang dan air terhadap daya putus mi dapat dilihat pada Tabel 1.

Menurut Djuragic et al. (2009), keseragaman ukuran bahan merupakan faktor yang sangat penting dalam proses mixing. Chen et al. (2011) menyatakan bahwa ukuran partikel memiliki peran yang sangat penting untuk menghasilkan adonan pasta yang sempurna, ukuran partikel penyusun adonan pasta diharapkan memiliki rentang perbedaan yang seminimal mungkin. Perbedaan ukuran partikel yang besar pada penelitian ini menyebabkan adonan yang terbentuk tidak bisa tercampur secara homogen. Ukuran partikel tepung yang digunakan pada pembuatan mi dalam penelitian ini, yaitu tepung porang sekitar 70 mesh (Faridah, 2012), tepung terigu 100 mesh (Ikhsanudin, 2010) dan MOCAF 100 mesh (Subagio, 2006). Kemungkinan salah satu penyebab semakin banyak konsentrasi tepung porang semakin mudah putusnya mi basah adalah karena perbedaan ukuran dari partikel tepung yang digunakan. Chen et al. (2011) melaporkan bahwa adonan yang mengandung dedak gandum ukuran partikel halus menunjukkan kekuatan lebih dari adonan yang mengandung dedak kasar yang diukur dengan Extensograf. Hal yang sama dilaporkan Chen et al. (2011) bahwa ukuran partikel tepung wheat bran (bekatul gandum) sangat berpengaruh nyata terhadap daya putus mi kering.

Data pada Tabel 1. menunjukkan daya putus terendah pada perlakuan penambahan porang $6 \%$ dan air $30 \%$, yaitu sebesar 0.0533 N. Sedangkan perlakuan dengan penambahan tepung porang $2 \%$ dan air $35 \%$ memiliki rerata daya putus dengan nilai yang tertinggi, yaitu $0.1433 \mathrm{~N}$. Silva et al. (2013) melaporkan bahwa penambahan $0.5 \%$ dan $1 \%$ konjak glukomanan dalam pembuatan mi semakin meningkatkan nilai daya putus mi yang berbahan $4 \%$ brokoli, namun pada mi yang berbahan $20 \%$ brokoli, penambahan $0.5 \%$ konjak glukomanan menurunkan nilai daya putus mi. Selain ukuran partikel tepung porang diduga komposisi tepung porang dan air berpengaruh terhadap daya putus mi. Tepung porang dapat menyerap air 200 x lebih banyak dari berat awalnya, jika konsentrasi air kurang, maka masih banyak tepung porang yang tidak larut dan membuat mi menjadi mudah putus dan permukaan kasar (mi dengan tepung porang $6 \%+$ air 30\%). Peningkatan nilai daya putus kemungkinan dapat diatasi dengan menggunakan tepung porang berukuran 100 mesh atau sama dengan tepung lainnya. Tepung porang berukuran lebih kecil lebih mudah larut atau memodifikasi tepung porang dengan cara menggunakan ekstrusi seperti pada penelitian Tatirat et al. (2012) yang dapat menghasilkan konjak glukomanan yang lebih kecil berat molekulnya. Selisih ukuran partikel akan menghasilkan proses mixing adonan yang maksimal.

\section{Volume pengembangan}

Rerata volume pengembangan mi basah pada kombinasi perlakuan penambahan tepung porang dan air adalah 102.29$104.75 \%$. Pengaruh penambahan tepung porang pada volume pengembangan mi basah dapat dilihat pada Tabel 2.

Tabel 2. Pengaruh penambahan tepung porang terhadap volume

\begin{tabular}{cccc}
\multicolumn{4}{c}{ pengembangan, kadar air, dan kecerahan warnami } \\
\hline $\begin{array}{c}\text { Tepung } \\
\text { Porang } \\
(\%)\end{array}$ & $\begin{array}{c}\text { Volume } \\
\text { Pengembangan } \\
(\%)\end{array}$ & $\begin{array}{c}\text { Kadar Air } \\
(\%)\end{array}$ & $\begin{array}{c}\text { Kecerahan } \\
\text { Warna }\end{array}$ \\
\hline 2 & $103.0152^{\mathrm{a}} \pm 1.1$ & $25.0675^{\mathrm{a}} \pm 2.12$ & $56.59^{\mathrm{b}} \pm 1.18$ \\
4 & $103.6559^{\mathrm{a}} \pm 0.31$ & $31.0474^{\mathrm{b}} \pm 2.46$ & $52.31 \mathrm{a} \pm 0.92$ \\
6 & $104.4429^{\mathrm{b}} \pm 0.48$ & $31.7349^{\mathrm{a}} \pm 2.17$ & $51.37^{\mathrm{a}} \pm 1.07$ \\
\hline
\end{tabular}

Keterangan: Angka yang ikuti dengan notasi berbeda menunjukkan berbeda nyata $(p<0.01)$ 
Perlakuan dengan penambahan tepung porang sebanyak $6 \%$ dan air $40 \%$ memiliki rerata volume pengembangan sebesar $104.75 \%$. Sedangkan rerata volume pengembangan terendah sebesar $102.29 \%$ pada perlakuan penambahan porang $2 \%$ dan air $30 \%$. Penambahan tepung porang berpengaruh pada volume pengembangan mi. Semakin tinggi tepung porang yang ditambahkan, maka akan semakin banyak pula air yang akan diserap. Sesuai dengan pernyataan Wojtowicz (2007) bahwa penambahan berbagai jenis emulsifier, stabilizer dan thickener akan meningkatkan volume pengembangan dari suatu produk pasta. Tepung porang merupakan salah satu jenis thickening agent yang memiliki kemampuan mengikat air yang sangat kuat (Charoenrein et al. 2011). Wen et al. (2008) juga menyebutkan bahwa glukomanan dalam air mampu mengembang hingga 200 $x$ berat awal.

Peningkatan konsentrasi air tidak berpengaruh terhadap volume pengembangan $\mathrm{mi}$, namun meningkat dengan meningkatnya konsentrasi air (Tabel 3.). Semakin banyak konsentrasi tepung porang akan semakin banyak air yang dibutuhkan, sehingga air meningkat karena tepung porang menyerap air untuk mengembang. Glukomanan mempunyai beberapa sifat yang istimewa diantaranya adalah dapat membentuk larutan yang kental dalam air, dapat mengembang dengan daya mengembang yang besar, dapat membentuk gel, dapat membentuk lapisan tipis dengan penambahan $\mathrm{NaOH}$ atau gliserin membentuk lapisan yang kedap air (Zhang et al. 2005).

Tabel 3. Pengaruh penambahan air terhadap volume pengembangan, kadar air, dan kecerahan warnami

\begin{tabular}{cccc}
\multicolumn{4}{c}{ kadar air, dan kecerahan warnami } \\
\hline $\begin{array}{c}\text { Air } \\
(\%)\end{array}$ & $\begin{array}{c}\text { Volume } \\
\text { Pengembangan }(\%)\end{array}$ & $\begin{array}{c}\text { Kadar Air } \\
(\%)\end{array}$ & $\begin{array}{c}\text { Kecerahan } \\
\text { Warna }\end{array}$ \\
\hline 30 & $103.36^{\mathrm{a}} \pm 1.26$ & $28.7422^{\mathrm{a}} \pm 3.66$ & $52.79^{\mathrm{b}} \pm 2.73$ \\
35 & $103.79^{\mathrm{a}} \pm 0.52$ & $29.37194^{\mathrm{a}} \pm 4.10$ & $51.72^{\mathrm{a}} \pm 2.68$ \\
40 & $103.96^{\mathrm{a}} \pm 0.79$ & $29.73565^{\mathrm{a}} \pm 3.84$ & $52.16^{\mathrm{a}} \pm 2.24$ \\
\hline
\end{tabular}

Keterangan: Angka yang ikuti dengan notasi berbeda menunjukkan berbeda nyata $(p<0.01)$

\section{Kadar air}

Rerata kadar air mi pada kombinasi perlakuan penambahan tepung porang dan air adalah $24.64-31.86 \%$. Tabel 2. Menyajikan rerata nilai kadar air yang dipengaruhi oleh perlakuan penambahan tepung porang. Semakin banyak penambahan tepung porang, maka kadar air mi basah semakin meningkat. Peningkatan kadar air disebabkan karena tepung porang memiliki kandungan glukomanan yang mampu menyerap air hingga $200 \mathrm{x}$ beratnya (Wen et al. 2008), sehingga semakin tinggi konsentrasi tepung porang dan air, maka semakin tinggi kadar air mi (Tabel 2. dan Tabel 3.).

Menurut BSN, 1992 kadar air yang boleh terdapat dalam mi adalah 20-35\%, hasil penelitian mi basah ini masih dalam range standar tersebut. Rerata kadar air terendah pada perlakuan penambahan porang sebanyak $4 \%$ dan air $35 \%$, yaitu sebesar $24.64 \%$, sedangkan rerata kadar air terbesar, yaitu $31.86 \%$ diperoleh pada perlakuan penambahan porang $6 \%$ dan air $40 \%$.

\section{Kecerahan warna}

Rerata nilai kecerahan warna mi berkisar $50.77-53.00$.
Tingkat kecerahan warna mi cenderung menurun dengan semakin banyaknya penambahan tepung porang (Tabel 2). Kecerahan warna produk makanan dipengaruhi oleh bahan baku. Mi dengan penambahan tepung porang cendrung lebih gelap karena warna tepung porang yang digunakan berwarna kekuning-kuningan. Hal ini sesuai dengan pernyataan Johnson (2007) bahwa tepung porang berwarna krem hingga coklat terang. Aravind (2012) melaporkan bahwa guar gum berpengaruh terhadap kecerahan warna spageti. Semakin tinggi kadar guar gum semakin rendah nilai kecerahan spageti yang dihasilkan. Berbeda dengan penambahan CMC, semakin banyak penambahan CMC akan semakin tinggi nilai kecerahan warna spageti. Kecerahan warna mi menurun dan berbeda nyata dengan penambahan air dari $30-35 \%$ dan tidak berbeda dengan penambahan air dari $35-40 \%$ (Tabel 3.). Solah et al. (2007) juga melaporkan hal yang sama, yaitu kecerahan mi menurun dengan penambahan air dari $30-35 \%$ dan tidak berbeda dengan penambahan air dari $35-38 \%$.

Secara keseluruhan penambahan tepung porang dan air berpengaruh terhadapsifat fisik mi, yaitu waktu pemasakan lebih cepat, KPAP, daya serap air, kadar air dan volume pengembangan lebih tinggi, sedangkan daya putus dan kecerahan warna lebih rendah.

\section{Perlakuan terbaik}

Perlakuan terbaik berdasarkan parameter sifat fisik adalah sampel dengan perlakuan penambahan tepung porang sebanyak $4 \%$ dan air $35 \%$. Produk mi hasil perlakuan terbaik ini selanjutnya dianalisis, yaitu kadar protein, lemak, abu, dan seratnya serta diamati mikrostrukturnya menggunakan SEM (Tabel 4.).

Tabel 4. Perbandingan karakteristik kimia dan fisik mi perlakuan terbaik dan mi kontrol

\begin{tabular}{lccc}
\hline \multirow{2}{*}{ Parameter } & Mi dengan & \multicolumn{2}{c}{ Mi Kontrol } \\
\cline { 3 - 4 } & Perlakuan & $\begin{array}{c}\text { Mi dari } \\
\text { Pasaran }\end{array}$ & $\begin{array}{c}\text { Mi tanpa } \\
\text { Perlakuan }\end{array}$ \\
\hline Waktu pemasakan & 2.13 & 4.62 & 4.21 \\
(menit) & & & 9.99 \\
KPAP (\%) & 7.03 & 0.17 & 0.10 \\
Daya putus (N) & 0.14 & 132.69 & 152.88 \\
Daya serap air (\%) & 201.58 & 59.79 & 55.78 \\
Warna & 51.41 & 97.99 & 89.88 \\
Vol. pengembangan (\%) & 103.63 & $15.50^{*}$ & 18.97 \\
Kadar air (\%) & 31.77 & $8.26^{*}$ & 5.97 \\
Protein (\%) & 5.87 & $2.99^{*}$ & 2.45 \\
Lemak (\%) & 2.13 & $1.23^{*}$ & 0.99 \\
Abu (\%) & 0.85 & $0.46^{*}$ & 0.98 \\
Serat kasar (\%) & 4.58 & & \\
\hline Keterangan : *Saragih et al. (2007) & & &
\end{tabular}

Produk mi hasil perlakuan terbaik dibandingkan dengan karakteristik fisik dan kimianya dengan mi kontrol (kontrol positif $=$ mi dari pasar dan kontrol negatif = mitanpa penambahan tepung porang). Perlakuan terbaik hasil formulasi ini diharapkan memiliki sifat fisik dan kimia yang menyerupai mikomersial pada umumnya. Perbandingan karakteristik fisik dan kimia mi kontrol dengan mi hasil perlakuan terbaik dapat dilihat pada Tabel 4. 
Khanna dan Tester (2006) menyatakan bahwa suhu dan lama gelatinisasi tergantung dari kandungan air dan banyaknya Purified Konjac Glucomannan (PKG). Hasil penelitian menunjukkan bahwa mi perlakuan terbaik memiliki waktu pemasakan yang lebih rendah $(2.13$ menit) dibandingkan dengan kontrol positif (4.62 menit) dan kontrol negatif (4.21 menit), karena kadar air tinggi dan PKG. Waktu pemasakan yang rendah lebih disukai konsumen karena akan mempercepat proses pemasakan dalam proses penyajian mi tersebut. Produk mi hasil perlakuan terbaik memiliki KPAP yang lebih rendah (7.03\%) dibandingkan dengan kontrol negatif $(9.32 \%)$. Hal ini dikarenakan adanya penambahan tepung porang yang bersifat memiliki kemampuan pengikatan air yang tinggi dibanding polisakarida lainnya (Wen et al. 2008), selain itu glukomanan juga mampu membentuk gel yang stabil. Sedangkan pada kontrol negatif tidak ada penambahan bahan pengikat, sehingga kehilangan padatan pada saat dimasak tinggi. Selain itu menurut Wardhana (2011) penggunaan atau penambahan tepung subtitusi (bukan terigu) akan meningkatkan KPAP pada mi. Mi di pasaran memiliki KPAP yang rendah dikarenakan bahan pembuatannya hanya dari tepung terigu yang memiliki kandungan gluten tinggi. Gluten tersebut membuat adonan menjadi lebih kokoh dan elastis (Torbica, 2010), sehingga kehilangan padatan selama pemasakan rendah.

Daya serap air mi dengan perlakuan terbaik sebesar $201.58 \%$, lebih tinggi dibandingkan dengan mi kontrol positif (132.69\%) maupun mi kontrol negatif (152.88\%). Hal ini dikarenakan tepung porang (Glukomanan) memiliki sifat mampu berperan sebagai water holding capacity dengan menyerap air hingga 200 kali lipat berat awalnya (Wen et al. 2008). Hal ini yang menyebabkan mi dengan penambahan tepung porang memiliki kemampuan menyerap air yang lebih tinggi daripada mi kontrol. Daya putus mi di pasaran lebih baik $(0.17 \mathrm{~N})$ dibandingkan dengan mi perlakuan $(0.14 \mathrm{~N})$ dan mi tanpa perlakuan $(0.10 \mathrm{~N})$. Hal ini dikarenakan mi di pasaran lebih tinggi kandungan glutennya (karena hanya menggunakan tepung terigu dalam proses pembuatannya) sedangkan pada penelitian menggunakan subtitusi parsial dengan MOCAF. Hal ini sesuai dengan pernyataan Yooet al. (2012) bahwa gluten yang berinteraksi (menyerap air) akan memiliki elastisitas dan kekokohan yang tinggi. Warna mi dengan perlakuan memiliki nilai yang lebih rendah, yaitu 51.41 (lebih gelap) daripada mi kontrol di pasaran (59.79) dan mi tanpa perlakuan (55.78). Penambahan porang dengan jumlah yang banyak akan membuat warna mi semakin gelap. Hal ini dikarenakan tepung porang yang ditambahkan dalam pembuatan mi ini memiliki warna coklat kekuningan seperti pernyataan Johnson (2007) bahwa warna tepung porang adalah coklat kekuningan.

Menurut BSN, 1992 kadar air yang boleh terdapat dalam mi adalah $20-35 \%$, hasil penelitian mi basah ini masih dalam range standar tersebut. Kadar air pada mi dengan perlakuan, yaitu $31.77 \%$, lebih tinggi daripada kadar air pada kontrol positif $(15.50 \%)$ maupun kontrol negatif $(18.97 \%)$. Hal ini disebabkan karena tepung porang merupakan salah satu jenis thickening agent yang memiliki kemampuan mengikat air (Charoenrein et al. 2011)

Serat pangan (dietary fiber) merupakan komponen bahan pangan yang tidak dapat dihidrolisis oleh enzim-enzim pencernaan tubuh manusia, namun berbagai penelitian menunjukkan bahwa perannya penting dalam kesehatan, sehingga dimasukkan ke dalam komponen yang memiliki sifat fungsional. WHO pada tahun 2003 telah menetapkan bahwa serat pangan memiliki kemampuan dapat menurunkan berat badan dan kegemukan yang berhubungan dengan sistem hormon dalam tubuh untuk mencerna dan mengontrol rasa lapar. Serat kasar (crude fiber) tidak identik dengan serat pangan. Serat kasar adalah bagian dari pangan yang tidak dapat dihidrolisis oleh bahan kimia yang digunakan untuk menentukan serat kasar yaitu asam kuat dan basa kuat.

Serat kasar pada mi dengan perlakuan terbaik, yaitu sebesar $4.58 \%$ lebih tinggi dibandingkan dengan serat kasar pada mi kontrol negatif $(0.98)$. Hal ini dikarenakan tepung porang yang digunakan memiliki kandungan serat yang tinggi. Kadar glukomanan pada tepung porang yang digunakan yaitu $80.17 \%$ yang merupakan serat larut air. Glukomanan merupakan serat larut air yang berpengaruh terhadap penurunan obesitas, meningkatkan aktivitas usus, penurunan kolesterol darah, diabetes, dan fungsi imun serta penyakit yang berhubungan dengan jantung (Wang dan Johnson, 2006; Li et al. 2005). Glukomanan sudah direkomendasikan FDA sebagai bahan yang aman dan dipergunakan sebagai pangan fungsional untuk penyakit gula dan adiposis. Aravind et al. (2012) juga melaporkan bahwa serat larut air yaitu guar gum dan CMC yang ditambahkan dalam pembuatan spageti berpengaruh mengurangi laju pelepasan gula.

\section{Mikrostruktur mi menggunakan SEM}

Produk mi sebelum dan setelah penambahan tepung porang yang belum dimasak diamati menggunakan SEM (Gambar 2).

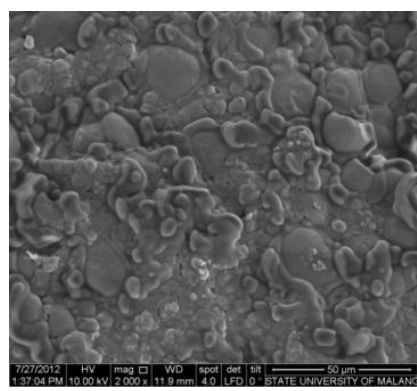

A

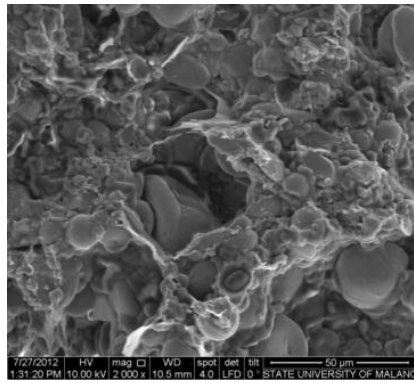

C

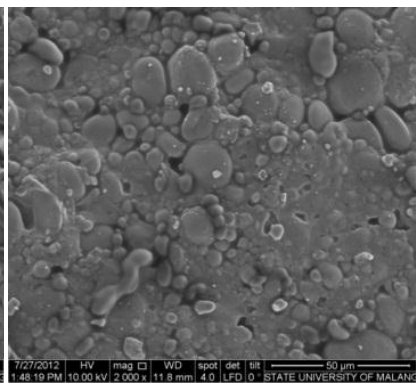

B

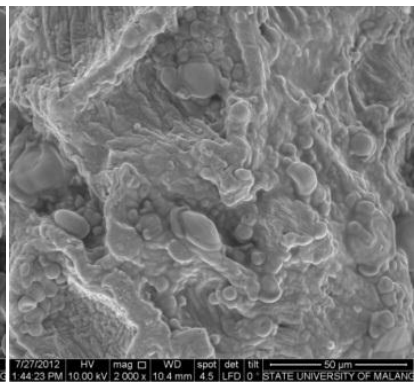

D
Gambar 2. Mikrostruktur mi sebelum dimasak: (A) kontrol (B) perlakuan terbaik $(C)$ kontrol dengan letak melintang $(D)$ perlakuan terbaik dengan letak melintang 
Permukaan mikro struktur pada kedua produk mi hampir sama (Gambar 2 A dan B), namun cenderung lebih halus pada mi dengan penambahan tepung porang. Tepung porang dengan sifatnya sebagai pembentuk gel diduga menyebabkan struktur mi lebih halus dan menutupi granula pati. Ding dan Yang (2013) mengamati mikro struktur mi yang ditambah emulsifier lebih halus dibandingkan dengan mi tanpa penambahan emulsifier karena terjadi interaksi hidrofobik antara emulsifier dengan gluten yang lebih rapat dibandingakan dengan mi tanpa emulsifier. Mikro struktur permukaan mi lebih halus dan matrik lebih kontinu serta struktur jaringan matrik gluten yang terbentuk lebih kuat dengan penambahan $0.5 \%$ sodium stearoyl lactylate (SLL) pada mi instan goreng (Choy et al. 2010).

Gambar $2 \mathrm{C}$ dan $\mathrm{D}$ memperlihatkan bahwa granula pati semakin tertutupi dengan penambahan tepung porang. Pendapat serupa dilaporkan oleh Aravind (2012), bahwa mikro struktur pati semakin tertutupi dengan semakin banyaknya guar gum yang ditambahkan pada spageti. Daya putus mi tanpa penambahan tepung porang lebih rendah (Tabel 4.), hal ini terlihat pada Gambar. 2 C mikro struktur lebih longgar dan berpori, kurang kompak dan masih banyak terlihat granula pati. Mercier (2011) mengatakan bahwa mikro struktur yang longgar dan berpori berhubungan dengan daya putus, makin longgar dan berpori strukturnya, maka makin rendah daya putusnya.

\section{KESIMPULAN}

Penambahan tepung porang dan air pada pembuatan mimemiliki pengaruh yang sangat nyata $(\alpha=0.01)$ pada sifat fisik mi parameter waktu pemasakan, KPAP, daya serap air, dan daya putus, kadar air, volume pengembangan dan kecerahan warna.

Mi perlakuan terbaik menurut sifatfisik dan kimia, yaitu dengan penambahan tepung porang $4 \%$ dan air $35 \%$. Produk mi tersebut memiliki karakteristik waktu pemasakan 2.13 menit, KPAP $7.03 \%$, daya putus $0.14 \mathrm{~N}$, daya serap air $201.58 \%$, kecerahan warna 51.41 , volume pengembangan $103.63 \%$, kadar air $31.77 \%$, kadar protein $5.87 \%$, kadar lemak $2.13 \%$, kadar abu $0.85 \%$, kadar serat kasar $4.58 \%$.

Mikro struktur mi dengan penambahan tepung porang $4 \%$ dan air $35 \%$ lebih halus, lebih rapat dan grunula pati lebih tertutupi dibandingkan dengan mikro struktur mi kontrol.

\section{DAFTAR PUSTAKA}

Alam F, Siddiqui A, Lutfi Z, Hasnain A. 2009. Effect of different hydrocolloids on gelatinization behaviour of hard wheat flour. Trakia J Sci 7: 1-6

Aravind N, Mike S, Fellows CM. 2012. Effect of soluble fibre (guar gum and carboxymethylcellulose) addition on technological, sensory and structural properties of durum wheat spaghetti. Food Chem 131: 893-900. DOI: 10.1016/ j.foodchem.2011.09.073.

Aydin E, Gocmen D. 2011. Cooking quality and sensorial properties of noodle supplemented with oat flour. Food Sci Biotechnol 20: 507-511. DOI: 10.1007/s10068-011-0070-1.
[BSN] Badan Standarisasi Nasional. 1992. SNI 01-2987. Jakarta.

Carini E, Vittadini E, Curti E, Antoniazzi F. 2009. Effects of different shaping modes on physico-chemical properties and water status of fresh pasta. J Food Eng 93: 400-406. DOI: 10.1016/j.jfoodeng.2009.02.002.

Charles AL, Huang TC, Lai PY, Chen CC, Lee PP, Chang YH. 2007. Study of wheat flour-cassava starch composite mix and the function of cassava mucilage in Chinese noodles. Food Hydrocolloid 21: 368-378. DOI: 10.1016/j.foodhyd. 2006.04.008.

Charoenrein S, Tatirat O, Rengsutthi K, Thongngam M. 2011. Effect of konjac glucomannan on syneresis, textural properties and the microstructure of frozen rice starch gels. Carbohyd Polym 83: 291-296. DOI: 10.1016/j.carbpol. 2010.07.056.

Chen JS, Fei MJ, Shi CL, Tian JC, Sun CL, Zhang $\mathrm{H}$, Ma Z, Dong HX. 2011. Effect of particle size and addition level of wheat bran on quality of dry white Chinese noodles. J Cereal Sci 53: 217-224. DOI: 10.1016/j.jcs.2010.12.005.

Chillo S, Suriano N, Lamacchia C, Del Nobile MA. 2009. Effects of additives on the rheological and mechanical properties of non-conventional fresh handmade tagliatelle. J Cereal Sci 49: 163-170. DOI:10.1016/j.jcs.2008.09.002.

Collado LS, Corke H. 2004. Noodles (Starch Asian Wheat Flour Noodles). 293-304. Elsevier Ltd, All Rights Reserved.

Choy AL, Hughes JG, Small DM. 2010. The effects of microbial transglutaminase, sodium stearoyl lactylate and water on the quality of instant fried noodles. Food Chem 122: 957964. DOI: 10.1016/j.foodchem.2009.10.009.

Choy A, Morrison PD, Hughes JG, Marriott PJ, Small DM. 2013. Quality and antioxidant properties of instant noodles enhanced with common buckwheat flour. J Cereal Sci 57: 281-287. DOI: 10.1016/j.jcs.2012.11.007.

De-Garmo ED, Sullivan WG, Canada JR. 1984. Engineering Company $7^{\text {th }}$ Edition. Mac Millan Publishing Company, New York.

Ding S, Yang J. 2013.The influence of emulsifiers on the rheological properties of wheat flour dough and quality of fried instant noodles. LWT-Food Sci Technol 53: 61-69. DOI: 10.1016/j.lwt.2013.01.031.

Djuragic O, Levic J, Sredanovic S, Levic L. 2009. Evaluation of homogeneity in feed by method of microtracers. Arch Zootech 12: 85-91.

Faridah A. 2012. Optimasi Pemurnian Glukomanan dari Umbi Porang (Amorphopallus $m$ ) dan Aplikasinya pada Pembuatan Mi Komposit. [Disertasi]. Malang: Teknologi Hasil Pertanian. Universitas Brawijaya.

Fu BX. 2008. Asian noodles: history, classification, raw materials, and processing. Food Res Int 41: 888-902. DOI: 10.1016/j.foodres.2007.11.007.

Gan CY, Ong WH, Wong LM, Easa AM. 2009. Effects of ribose, microbial transglutaminase and soy protein isolate on physical properties and in vitro starch digestibility of yellow noodles. LWT-Food Sci Technol 42: 174-179. DOI: 10.1016/ 
j.lwt.2008.05.004.

Hou GG. 2010. Preface. In: Hou GG. (Ed.), Asian Noodles: Science, Technology, and Processing. John Wiley \& Sons, Inc, Hoboken, New Jersey, pp. Ix-xii.

Huang YC, Lai HM. 2010. Noodle quality affected by different cereal starches. J Food Eng 97: 135-143 DOI: 10.1016/j. jfoodeng.2009.10.002.

Ikhsanudin A. 2010. Laporan Magang di PT Indofood Sukses Makmur Tbk. Bogasari Flour Mills Divisi Tanjung Priok Jakarta Utara [Laporan Magang]. Surakarta: Fakultas Pertanian. Universitas Sebelas Maret.

Izydorczyk M, Steve WC, Qi W. 2005. Polysaccharide Gums: Structures, Functional Properties, and Applications, In Cui, Steve W (Ed). 2005. Food Carbohyd : Chemistry, Physical Properties, and Applications. 307-352. CRC Press Taylor \& Francis Group, Boca Raton.

Johnson A. 2007. Konjac - an introduction.http://www.konja c.info/. [28 Agustus 2009].

Khanna S, Tester RF. 2006. Influence of purified konjac glucomannan on the gelatinisation and retrogradation properties of maize and potato starches. J Food Hydrocolloid 20: 567-576. DOI: 10.1016/j.foodhyd. 2005.05.004.

Lase VA, Julianti E, Lubis LM. 2013. Mi tipe bihun dari pati heat moisture treatmen dari empat variates ubi jalar. J Teknol dan Industri Pangan 24: 89-96. DOI: 10.6066/jiti.2013.24.1.89.

Li B, Xia J, Wang Y, Xie B. 2005. Grain-size effect on the structure and antiobesity activity of konjac flour. J Agr Food Chem 53: 7404-7407.

Yoo J, Kim Y, Yoo SH, Inglett GE, Lee S. 2012. Reduction of rutin loss in buckwheat noodles and their physicochemical characterisation. Food Chem 132: 2107-2111. DOI: 10.1016/j.foodchem.2011.12.065.

Mercier S, Marchais LD, Villeneuve S, Foisy M. 2011. Effect of die material on engineering properties of dried pasta. Procedia Food Sci 1: 557-562. DOI: 10.1016/j.profoo. 2011.09.084.

Ratnaningsih, Permana AW, Richana N. 2010. Pembuatan Tepung Komposit dari Jagung, Ubi Kayu, Ubi Jalar dan Terigu (Lokal dan Impor) untuk Produk Mi. Prosiding Pekan Serealia Nasional. Jakarta.

Silva E, Birkenhake M, Scholten E, Sagis LMC, Linden EV. 2013. Controlling rheology and structure of sweet potato starch noodles with high broccoli powder content by hydrocolloids. Food Hydrocolloid 30: 42-52. DOI: 10.1016/j. foodhyd.2012.05.002.
Solah VA, Crosbie GB, Huang S, Quail K, Sy N, Limley HA. 2007. Measurement of color, gloss, and translucency of white salted noodles: Effects of water addition and vacuum mixing. Cereal Chem 84: 145-151. DOI: 10.1094/CCHEM84-2-0145.

Subagio A. 2006. Ubi kayu substitusi berbagai tepungtepungan. Food Review 3:18-22.

Tatirat O,Charoenrein S, Kerr WL. 2012. Physicochemical properties of extrusion-modified konjac glucomannan. J Carbohyd Polym 87: 1545-1551. DOl: 10.1016/j.carbpol. 2011.09.052.

Torbica A, Hadnadev M, Dapcevic T. 2010. Rheological, textural and sensory properties of gluten-free bread formulations based on rice and buckwheat flour. Food Hydrocolloid 24: 626-632. DOI: 10.1016/j.foodhyd.2010. 03.004.

Wang W, Johnson A. 2006. Konjac introduction. http://www. cybercolloids.net/library/konjac/introduction.php. [9 Maret 2009].

Wardhana GG. 2011. Pengaruh Proporsi MOCAF: Tepung Beras dan Penambahan Tepung Porang terhadap Sifat Fisik, Kimia, dan Organoleptik Mi Kering [Skripsi]. Malang: Fakultas Teknologi Pertanian. Universitas Brawijaya.

Wen X, Wang T, Wang Z, Li L, Zhao C. 2008. Preparation of konjac glucomannan hydrogels as DNA-controlledrelease matrik international. Int J Biol Macromol 42: 256-263. DOI: 10.1016/j.jijbiomac.2007.11.006.

Wojtowicz A. 2007. Effect of monoglyceride and lecithin addition on cooking quality of precooked pasta. Pol J Food Nutr Sci 57: 157-162.

Wu JP, Corke H. 2005. Quality of dried white salted noodles affected by microbial transglutaminase. J Sci Food Agr 85: 2587-2594. DOI: 10.1002/jsfa.2311.

Xiong ZC. 2007. Preparation and properties of thermo-sensitive hydrogels of konjac glucomannan grafted $n$ isopropylacrylamide for controlled drug delivery. Iran Polym J 16: 425-431.

Xu YY, Clifford H, Wolf-Hall C, Manthey F. 2008. Fungistatic activity of flaxseed in potato dextrose agar and a fresh noodle system. Int J Food Microbiol 121: 262-267. DOl: 10.1016/j.jijfoodmicro.2007.11.005.

Zhang YQ, Xie BJ, Gan X. 2005. Advance in application of konjac glucomannan and its derivatives. Carbohyd Polym 60: 27-31. DOI: 10.1016/j.carbpol.2004.11.003. 